\title{
COLONIAL BOUNDARIES AND THE QUESTION OF THE LEGITIMACY OF CONSTITUTIONAL CONTROL OVER TRANS BORDER CRIMINALITY IN AFRICA
}

\author{
LIMITES COLONIAIS E A QUESTÃO DA LEGITIMIDADE \\ DO CONTROLE DE CONSTITUCIONALIDADE DA \\ CRIMINALIDADE TRANSFONTEIRIÇA NA ÁFRICA
}

Ernest Duga Titanji

\begin{abstract}
This paper seeks to examine how arbitrary colonial boundaries help to create fertile ground for the challenge of constitutional legitimacy to fight against trans border criminality in some African countries and how porous borders and tribal or cultural solidarity contribute to trans border or transnational criminality. The paper explores the role played by successive State constitutions in framing laws and procedures to fight against cross border criminality and the challenges they face in trying to implement these constitutional dispensations. The paper further examines the difficulties faced by national jurisdictions to prosecute the perpetrators of these trans border crimes without a direct and unalloyed collaboration from the neighbouring countries. It makes a gloss on the rise of criminal organizations in one State that operate in another State with or without the complicity of the host State and the failure of the host State to act or sanction such trans border criminal organizations when those acts are not perpetrated within their territory especially when those acts do not impact negatively on their daily activities. The paper also examines those hurdles inherent in the nature of transnational criminality itself and in the processes and procedures to prosecute such offences such as the principle of dual criminality when the offence may not be an offence in one of the concerned
\end{abstract}


States. The paper finally examines the cooperation mechanisms to be put in place for the effective implementation of criminal laws in adjoining countries and opens up a discussion on the human rights implications of enforcing constitutional and penal sanctions on people who do not believe they belong to that State and who believe they are victims of a colonial accident without which they will not be subject to the application of those specific laws.

Keywords: Constitutional Colonial Heritage. Constitutional-legitimacy. Cultural Solidarity. Transnational criminality. Judicial Cooperation.

\section{RESUMO}

Este artigo examina como as fronteiras coloniais arbitrárias ajudam a criar um terreno fértil para o desafio da legitimidade constitucional para lutar contra a criminalidade transfronteiriça em alguns países africanos e como as fronteiras porosas e a solidariedade tribal ou cultural contribuem para a criminalidade transfronteiriça ou transnacional. 0 artigo explora o papel desempenhado pelas sucessivas constituições dos novos países africanos, e na formulação de leis e procedimentos para lutar contra a criminalidade transfronteiriça e os desafios que enfrentam ao tentar implementar essas normas constitucionais. 0 documento ainda examina as dificuldades enfrentadas pelas jurisdições nacionais para processar os autores desses crimes transfronteiriços sem uma colaboração direta e absoluta dos países vizinhos. Ele dá destaque ao aumento de organizações criminosas de um país que operam em outro território nacional com ou sem a cumplicidade do Estado anfitrião e a falha do Estado anfitrião em agir ou punir tais organizações criminosas transfronteiriças quando esses atos não são perpetrados dentro de seu território, especialmente quando esses atos não impactam negativamente em suas atividades diárias. 0 documento também examina os obstáculos inerentes à própria natureza da criminalidade transnacional e aos processos e procedimentos para persecução de tais crimes, como o princípio da dupla incriminação, quando o crime pode não ser um tipo penal em um dos estados em questão. $O$ artigo finalmente examina os mecanismos de cooperação a serem implementados para efetivação das leis criminais nos países vizinhos e abre uma discussão sobre as implicações dos direitos humanos da aplicação de sanções constitucionais e penais a pessoas que não acreditam pertencer a esse Estado e que se considerem vítimas de um acidente colonial, sem o qual não estarão sujeitos à aplicação dessas leis específicas.

Palavras-chaves: Herança Colonialista Constitucional. Legitimidade Constitucional. Solidariedade Cultural. Criminalidade Transnacional. Cooperação Judicial. 


\section{INTRODUCTION}

It is a truism that with the advent of globalization, the world has now become so interconnected that it can be considered a global village. This new interconnectedness has given rise to so much interdependency that there is hardly any State that can survive without the existence of the others. A reflection to the reverse is that most African States initially belonged to a sort of village-setting before they were split up along imaginary lines and divided to various European colonial masters following the partition of Africa at the now infamous Berlin Colonial Conference of $1884-1885 .{ }^{1}$ During that conference, the continent of Africa was divided into States not based on the concept of nationhood as had grown in Europe ${ }^{2}$ at the time when European States were created, but based on the egoistic interest of some European States that became colonial masters after the partition of Africa. ${ }^{3}$ The consequence was that some African nations were split up, and peoples with a common language and culture found themselves as citizens of two and sometimes three different States. ${ }^{4}$ Increasing calls for a reversal of this situation in certain cases have met with stiff opposition and the international law principle uti possidetis juris ${ }^{5}$ has been used to counter such claims when they have been brought before any international adjudicatory or quasi adjudicatory body. But human solidarity and cultural proclivity are factors that cannot be underestimated. As a consequence, increasingly the peoples, though belonging to different States and countries, still feel so attached to each other that in certain circumstances are willing to prefer their tribal appurtenances to national interest, to the extent that they do lend a helping hand to "criminals" operating in neighbouring countries to provide them a safe harbour when they have committed crimes in those States. This is true with the Boko Haram insurgency that spreads through Northern Nigeria and Northern Cameroon ${ }^{6}$ and the Cameroon Anglophone and Nigerian Biafra cases ${ }^{7}$ that are now known to lend a helping hand to each other. In either case, the argument begins by challenging the colonial partition of the territory before challenging the constitutional powers to regulate State issues as concerns those particular groups of persons. 
This paper seeks to examine how arbitrary colonial boundaries help to create fertile ground for the challenge of constitutional legitimacy to fight against trans border criminality in some African countries and how porous borders and tribal or cultural solidarity contribute to trans border or transnational criminality. The paper explores the role played by successive State constitutions in framing laws and procedures to fight against cross border criminality and the challenges they face in trying to implement these constitutional dispensations. The paper further examines the difficulties faced by national jurisdictions to prosecute the perpetrators of these trans border crimes without a direct and unalloyed collaboration from the neighbouring countries. It makes a gloss on the rise of criminal organizations in one State that operate in another State with or without the complicity of the host State and the failure of the host State to act or sanction such trans border criminal organizations when those acts are not perpetrated within their territory especially when those acts do not impact negatively on their daily activities. The paper also examines those hurdles inherent in the nature of transnational criminality itself and in the processes and procedures to prosecute such offences such as the principle of dual criminality when the offence may not be an offence in one of the concerned States. The paper finally examines the cooperation mechanisms to be put in place for the effective implementation of criminal laws in adjoining countries and opens up a discussion on the human rights implications of enforcing constitutional and penal sanctions on people who do not believe they belong to that State and who believe they are victims of a colonial accident without which they will not be subject to the application of those specific laws.

\section{EARLY AFRICAN NATIONS AND THE PARTITION OF AFRICA - SOWING THE SEEDS FOR FUTURE CONSTITUTIONAL DISCORD}

Before the arrival of the first Europeans in Africa, the continent was well organized with kings reigning over kingdoms ${ }^{8}$ that were akin to the nations of Europe. Nationhood here refers to Max Weber's conception of 
a nation constituting a common territory, a common language, a common boundary and a group of peoples. ${ }^{9}$

The first Europeans that arrived were looking for trade routes to either buy or sell spices to the east and not necessarily to colonize or dominate the people on the continent of Africa. That is why they signed treaties most of them commercial contracts with the different kings that they met and encountered to secure trade deals. ${ }^{10}$

It wasn't until around 1884 when Otto Von Bismarck organized a colonial conference in Berlin, that Africa was partitioned to the Europeans that were present at that conference. For the purpose of this article, 5 anomalies that were inherent in this conference are highlighted here:

1. No African and no one representing the African States was present at the conference. That means the interest of the African States was of no importance and it did not matter who was lumped where.

2. The distance also constituted an anomaly. The conference was held thousands of miles away from the African continent. Which means, all what was discussed and the decisions taken were based on what someone claimed to know without any possibility of verification given that the knowledge of the geography of the continent back then was not as precise as it is today. There are picture sketches of the conference that present a map of Africa as a blank sheet with only streams and rivers because there were large parts of Africa that no European had ever stepped foot on. ${ }^{11}$ It is even said that after the partition, there were still vast parts of Africa that really did not belong to any European power. ${ }^{12}$

3. Those European States that had treaties with certain kingdoms claimed ownership over those kingdoms and territories and the rest were distributed to the other European powers who were present without taking into consideration their understanding of the territory. This caused a disregard of the autonomy of those areas that were properly constituted with kings representing their interests when the early Europeans came to the continent to the extent that they even entered into treaties with them. 
4. The other problem is that, even those who had treaties did not master the territorial limits of the kingdoms with which the treaties were signed thereby causing a mix of peoples and populations in the distribution.

5. There are clear instances where the powers were blocked in the distribution of territory and they merely drew an arbitrary line to attribute territory to the powers. ${ }^{13}$ The direct consequence of this was that kingdoms were split and granted to different colonial masters thereby creating different countries out of one kingdom with a people, common language and common culture. Families were also split along the same lines with one family now belonging to two different countries.

All these are factors that one can argue were only going to sow the seeds for future problems as human bond and the African family is so strong that a simple stroke of the pen cannot dissolve.

\section{THE PRESENT-DAY StateS AND THE RISE OF TRANS BORDER AND TRANS NATIONAL CRIMINALITY IN SOME AFRICAN STATES (THE CASE OF CAMEROON AND NIGERIA - BOKO HARAM AND THE SOUTHERN CAMEROONS QUESTION)}

Two of such States that were carved out of the abovementioned arrangements are Nigeria and Cameroon as they stand today. Historically, the territory belonged to the Central and West African kingdoms. When the early Portuguese arrived Cameroon, they signed trade treaties with the Kings of Douala and named the territory Rio Dos Cameroes (the river of shrimps). ${ }^{14}$ Those who arrived in the present-day Nigeria (formerly Lagos ) signed treaties with Oba Akitoye, the Oba of Lagos. ${ }^{15}$

At the Berlin Colonial Conference, the territory of Cameroon was handed over to Germany as a protectorate and named Kamerun with a "K" to show its "Germaness". That notwithstanding, Germany still signed the Germano-Duala Treaty with King Ndumbe Lobe Bell and King Akwa of 
Cameroon Rivers (Wouri River) on $12^{\text {th }}$ July $1884 .{ }^{16}$ Nigeria on its part was handed to the British. But a boundary had to be drawn between the two countries. That is where the problem arose. As indicated above, neither the Germans nor the British mastered the local boundaries between the kingdoms of West and Central Africa. So they drew an imaginary line running from Yola in the north to Calabar in the south right down to the Atlantic ocean. ${ }^{17}$ It is worth noting that this arbitrariness has also led to an international dispute over the boundary between Cameroon and Nigeria in this territory. ${ }^{18}$ So it in not only a problem with the division of kingdoms, villages and families but even after the decision in the Cameroon/Nigeria Case over the Bakassi Peninsula, the procedure in determining and defining the right boundary is still ongoing after over 22 years of the judgement. ${ }^{19}$

The direct consequence of this is that the peoples still have their bonds in place. In the northern parts which is a vast desert, the story is even told of how a village is split up into two; one part belonging to Nigeria and the other part to Cameroon and that there are instances where a house or building is split up one part in Nigeria and the other in Cameroon. In the southern part which consists mostly of vast forests, some of the villages were completely hidden in the forest that they went unnoticed at the time of drawing the map and it wasn't so clear where they belonged.

Under such circumstances, it is difficult to dictate a nationality to someone who has grown up knowing that the people around him were brothers and sisters to him rather than persons of different countries and nationalities. That was the case with the inhabitants of the Bakassi peninsula when they were told their land belonged to Cameroon and not Nigeria and that they were Cameroonians and not Nigerians. Most of them opted to leave the peninsula to go and settle in Nigeria rather than stay there and be considered as Cameroonians.

Naturally, even under such circumstances, the movement alone will not break the bond of solidarity. As will be seen, there is still a lot of cooperation and collaboration between the peoples especially with the rise of the Southern Cameroons question and the Boko Haram uprising. 


\section{DOMESTIC CONSTITUTIONS, NATIONAL CRIMINAL LAWS AND THE CHALLENGES FACED IN CROSS BORDER OR TRANS NATIONAL PROSECUTIONS}

The criminal laws of the State are derived from its constitution. The constitution determines under what conditions a body of laws can be made that will define and punish certain acts as criminal. Both States (Cameroon and Nigeria) have under their constitutions arrogated the right to prosecute and punish the perpetrators of certain crimes. The State of Cameroon has enacted laws notably the anti-terrorism law ${ }^{20}$ to fight against violence perpetrated by terrorist groups. This law prohibits and sanctions acts of terrorism. Nigeria also has a similar law. ${ }^{21}$

But the problem arises where the crime is planned in one State and executed in another. Or when the perpetrators live simultaneously and freely in both States as a result of their historical origins. Which State, therefore, will be competent to try them if the crime is not committed in that State?

There was a time when Nigeria accused Cameroon that Cameroon was harboring Boko Haram terrorists and that when they attacked in Nigeria they escaped and settled in Cameroon that provided them with a safe harbor. Nigeria could not chase the terrorists into Cameroonian territory for fear of breaching the principle of sovereignty of territorial boundaries. This misunderstanding was only finally resolved by the creation of a mixed military force between Cameroon and Nigeria to control the area and fight against the terrorists at least preventing their free movement from one country to the other. ${ }^{22}$

However, this solution was only military in nature. It is still not clear which State is competent and the laws of what State is applicable to try terrorists of Boko Haram if they are arrested in the other country that is not the country of their nationality. Without necessarily dwelling on principles of international law on how to handle instances of this nature, we will strongly submit that both States should simply ratify and apply principles of international criminal law that will make either State competent.

From a more general criminal law perspective, there are at least three main factors that militate against the application of the anti-terrorism 
laws promulgated by one State by another State. The arguments are of a political, ideological and judicial nature.

The political argument is to the effect that the definition of terrorism will affect the rights of the so-called "freedom fighters". Others have also argued that the definition of terrorism should not and do not in most cases cover acts committed by the armed forces of States. ${ }^{23}$ There is a marked difference in the approach to terrorism between developing and developed countries. While developing countries tend to exclude the actions of national liberation movements from the concept of terrorism, developed countries have confined the use of the term to violence by those opposing the established order. ${ }^{24}$ In all, the main challenge of determining who is a terrorist depends on the international perception of the situation at the moment of conception of the crime, for as it is often puts: "One man's terrorist is another man's freedom fighter."25

The problem was accurately summarized by the Special Rapporteur of the UN Sub-Commission on Human Rights:

It may be that the definitional problem is the major factor in the controversy regarding terrorism. This is all the more true when considering the high political stakes attendant upon the task of definition. For the term terrorism is emotive and highly loaded politically. It is by an implicit negative judgment and is used selectively. In this connection, some writers have aptly underlined a tendency amongst commentators in the field to mix definitions with value judgments and either qualify as terrorism violent activity or behaviour which they are opposed to or, conversely, reject the use of the term when it relates to activities and situations which they approve of. Hence, the famous phrase 'one man's terrorist is another man's freedom fighter."26

While public discourse about terrorism frequently focuses on nonState actors, the possibility that State agents might directly or indirectly support or perpetrate acts of terrorism is something that some States feel has to be included in a Comprehensive Convention. ${ }^{27}$

From the ideological perspective, the lack of a clear and universally accepted definition of terrorism in international law is another factor that lends credibility to the refusal of the definition of one State to the application in another State. This argument is all the more important when one has to look as the condition of dual criminality in order to prosecute 
and punish acts perpetrated in another country. ${ }^{28}$ Furthermore, it has been argued that States should include in their definition those acts such as the State's use of force against its own civilians (State terrorism) and exclude from their definition the case of opposition to foreign occupation (right of self-determination and the recourse to force used by groups who assert such a right and the countries that support them). ${ }^{29}$

The judicial argument is to the effect that States may lose sight of terrorism laws as exceptional legislation and use it to settle other scores or for different purposes. The point here is that the terrorism law should not turn innocent individuals into victims. The State should guard against what is referred to as the "windfall", "discrimination" and "contamination" effects. The "windfall" effect is the "ability of extending the field of application of anti-terrorism measures beyond their original scope."30 It deals with the ease with which States can succumb and lose sight of the exceptional character of the crime of terrorism and the limits to the phenomenon that they seek to combat and embrace other forms of crimes that have nothing to do with terrorism in their definition of terrorism.

A quick look at the Cameroon Law on terrorism reveals this trend. The law includes such acts as the creation of widespread insurrection, ${ }^{31}$ the disruption of the functioning of public services, ${ }^{32}$ acclamation of acts of terrorism, ${ }^{33}$ and false Statements of a defamatory nature. ${ }^{34}$ The "discrimination" effect refers to the uncertainty that clouds the threat of terrorism and leads to increased discrimination and a feeling of anguish.

Finally, the "contamination" effect is the argument that the confusion between the ideology of the terrorist action and the ideology of the demands and opinions defended especially by the terrorists are accompanied by a political, ideological or religious message such that certain social groups will adhere to this philosophy. In the Boko Haram case, the ideology is that of Islam and the spread of Islamic fundamentalism that initially was not widely accepted by the population but as time went on saw an increase in enrolment by the youths of the northern States of Cameroon and Nigeria. In the Southern Cameroons case, the ideology of secession was not welcome at the beginning of the movement but with time it has witnessed a change of mentality even from the most neutral and most opposed anglophones who increasingly are buying into the ideology of secession. 


\section{OBSTACLES INHERENT IN THE APPLICATION OF INTERNATIONAL CRIMINAL LAW PRINCIPLES}

There is a general obligation on a State in which a fugitive finds himself to prosecute and punish that fugitive or extradite him to another State that will prosecute and punish him (aud dedere aut judicare). This principle, as simple as it may sound, is not without its own challenges. In order for a State to prosecute and punish someone for a crime committed in another country, that State must not only have laws, statute, or some sort of judge-made legal regulation punishing those crimes, but it must also have legal provisions authorizing its courts to prosecute and punish perpetrators of the alleged crimes. There must therefore be some sort of a jurisdictional link between the offence, its alleged author or the victim and the State in question.

In very general terms, States bring alleged perpetrators of international crimes for trial before their domestic jurisdiction on the basis of one of three principles: Territoriality (that is, the principle that the offence has been perpetrated on the State's territory), Passive nationality (that is, the victim is a national of the prosecuting State) and Active nationality (that is, the perpetrator is a national of the prosecuting State).

Based on these very general principles, one can easily decipher that it is usually not easy for the judiciary in either Nigeria or Cameroon to prosecute and punish the cases of terrorism that arise from acts committed either by Boko Haram and worse still by the Anglophone secessionists because they will have to prove that the acts were either committed within their national territorial boundaries, or that the victims are their nationals or again that the perpetrators are their nationals. We will return to these points in the subsequent lines.

Recently, a fourth principle known as the principle of universality has emerged whereby any State is empowered to bring to justice alleged authors of international crimes, especially so where the authors happen to be present on the territory of the prosecuting State. However, other than for the crime of piracy where the customary international law grants universal jurisdiction to all States to arrest and bring to justice persons suspected of engaging in piracy, whatever their nationality and 
the place of commission of the crime; in the case of universal jurisdiction in general, the State has to claim it and exercise it. Most States see the claim of universal jurisdiction by another State to prosecute and punish their nationals as a violation of their sovereignty as it is argued that States courts will interfere in the internal affairs of another State, in violation of the fundamental principle of international relations and that national courts will hinder international diplomatic relations whenever the suspect or the accused is a State agent in office, such as presidents or diplomats.

The situation of the Southern Cameroonians resident in Nigeria who were accused of crimes of terrorism presented complex challenges for their prosecution and punishment in Nigeria. But for the argument against the sweeping and generalized definition of terrorism provided by the Cameroonian legislator, the definition of terrorism under Nigerian Law does not include freedom fighters as terrorists hence they could not be brought before any court in Nigeria. And secondly, their victims, if any, were neither nationals of the State of Nigeria nor resident in Nigeria. So, the only avenue opened in international criminal law was their extradition to Cameroon to stand trial for the acts for which they were accused.

However, as mentioned above, where one of the above conditions is fulfilled, the State will have the obligation to either prosecute or extradite in accordance with the international law principle aut dedere aut judicare.

Even when the State decides to extradite, it will also face certain rules of international criminal law that it must respect. These will include such conditions as the fact that the offence must be an extraditable offence, that it must fulfill the requirement of the principle of dual criminality, that the role of evidence must be satisfied, and that all factors that might obstruct extradition must be duly dealt with.

The condition that the offence must be an extraditable offence is an easy one to fulfill because it simply requires looking at the punishment in both domestic laws to compare if the offence falls under a category that is worth undergoing the trouble of the length and complexity of the extradition process. Hence simple offences are not extraditable offences and only misdemeanours and felonies would qualify as extraditable offences.

The second obstacle is that of dual criminality which is the condition that the requisite conduct should amount to an extraditable offence in 
both States. What this means is that, the offence must actually exist as an offence punishable in both States. If it is an offence in one State and not an offence in the other State, then it cannot be extraditable. This probably explains why in the case of Ayuk Tabe and others, the State of Cameroon resorted to kidnapping. ${ }^{35}$

Furthermore, the different approaches to the issue of the level of evidence to be adduced at the extradition hearing is or importance. There are basically three main approaches to the issue of evidence in the extradition process namely the non-evidence approach, the prima facie case approach, and the probable cause approach. These are not subjects of discussion for this paper and will not be treated here.

In any case, even if the matter had gone for an extradition hearing, the argument that the accused are freedom fighters would have been raised. That leads us to a discussion of freedom fighters and the human rights implications in the trial of the offence of terrorism before domestic courts.

\section{INTERNATIONAL LAW AND HUMAN RIGHTS IMPLICATIONS OF APPLICATION OF DOMESTIC CRIMINAL LAW ON FREEDOM FIGHTERS}

As mentioned earlier, there is no universal agreement on the application of the status of terrorist to freedom fighters. The argument is that the freedom fighter is reacting against of form of oppression that is akin to State terrorism. Where the State systematically violates the rights of a group of persons, such a group may be justified to fight against the State where the State is not open to dialogue or to the respect of the rights of those persons as human beings. ${ }^{36}$

The concept of the "rule of law" is the pillar stone of the international framework for the fight against terrorism. Even though it is widely recognized by the UN and States that terrorism threatens both the rule of law and the fundamental freedoms of citizens and entire societies, it is however, argued that one wrong cannot be used to correct another wrong. Hence even in the fight against terrorism, the rule of law together with "human rights, fundamental freedoms and democracy must be respected..."37 
Consequently, inappropriate counter-terrorism responses which do not adhere to the rule of law ${ }^{38}$ can both undermine their legality and effectiveness, while furthering such counter terrorist agendas.

The whole argument of the Southern Cameroons fighters is that they are freedom fighters and not terrorists. They challenge the colonial and successive State arrangement that puts them under the Republic of Cameroon. They seek to have their own State since they constitute a people, with a common culture, language, and clearly distinct geographical boundaries. In short, they argue that they qualify to have a State under Max Weber's conception of Statehood. All what is lacking, is recognition.

They argue that they can therefore not be justiciable before the courts of a country that they consider foreign to theirs. If that were the case, then international standards and principles would have to be applied to them.

Also, there is a lot of human rights issues that are raised in the trials. Should rights be violated even if someone is considered a terrorist? This whole argument is exacerbated by the human rights violations that are inherent in the trials of those accused of terrorism and the unreasonable punishments that are meted on them. Even their conditions of detention are not the best. ${ }^{39}$ Those who were kidnapped from Nigeria have disappeared and no has one has seen any of them since January 2018 or at least they are being held in communicado for over 6 months now. ${ }^{40}$

Whole villages have been razed and there is continuous killing of innocent civilians. Where is the place of human rights in the trials? But can one be tried by a court that he does not consider to be competent and impartial ${ }^{41}$ In a situation of de facto, if at all, but not de jure Statehood, can one State try the citizens who claim independence for secession? Is secession on grounds of human rights violations a crime in international law?

In any case, if these instances constitute crimes that States consider as terrorism, they however present abundant human rights issues such as torture, arrest and detention, fair trial and punishment, and privacy and surveillance. ${ }^{42}$

In the context of counter-terrorism, UN organs and entities regularly convey the strong message that respecting human rights while countering terrorism is not only a matter of legal obligation, but it is 
critical to the ultimate success of any counter-terrorism strategy. This is illustrated by a recent report of the UN High Commissioner for Human Rights that States that:

Effective counter-terrorism measures and the protection of human rights are complementary and mutually reinforcing objectives, which must be pursued together as part of States' duty to protect individuals within their jurisdiction. Experiences in countries around the world have demonstrated that protecting human rights and ensuring respect for the rule of law itself contribute to countering terrorism, notably by creating a climate of trust between the State and those under their jurisdiction. ${ }^{43}$

This is illustrated by the indivisible relationship between international human rights law and criminal law (both national and international). From a rule of law perspective, the essence of criminal law is to delineate the parameters of what constitutes acceptable and unacceptable behaviour within a particular societal context. If, for example, the definitions of offences are ambiguous then the main function of criminal law may be undermined, thereby facilitating the possibility of other executive-led actions which may be contrary to upholding the rule of law.

Furthermore, UN organs and entities, including the UN General Assembly and Security Council, regularly emphasize the importance of adhering not only to international human rights law, but also to international humanitarian law and international refugee law, ${ }^{44}$ notably within the context of the UN Global Counter-Terrorism Strategy. ${ }^{45}$

\section{INTERNATIONAL COOPERATION FOR EFFECTIVE IMPLEMENTATION OF CRIMINAL LAWS IN ADJOINING COUNTRIES}

The issue of terrorism is so important that the UN has put in place a strategy to counter it. This is under the auspices of the UN Counter Terrorism (UN CT) strategy which was adopted by the UN General Assembly in Resolution 60/288 on 8 September $2006^{46}$ without a vote.

The UN CT Strategy is a unique global instrument to enhance national, regional and international efforts to counter terrorism, including by strengthening cooperation between all key actors. The Strategy enumerates 
the many levels on which international cooperation must take place and also highlights the necessity for the commitment of Member States in working together to combat terrorism. The Strategy finally expresses the international community's resolve to cooperate fully in the fight against terrorism, in accordance with its obligations under international law, in order to find, deny safe haven and bring to justice, on the basis of the principle of extradite or prosecute, any person who supports, facilitates, participates or attempts to participate in the financing, planning, preparation or perpetration of terrorist acts or provides safe havens. ${ }^{47}$

\section{CONCLUSION}

This paper at the beginning examined the role played by the partition of Africa in the development of dissatisfaction and the rise of claims for independence or autonomy for certain areas based on tribal lines. In the previous section it highlights the need for international cooperation to counter global terrorism and even trans border terrorism and crimes. However, it can be argued that international cooperation is addressed to States because the international community regards only States as being part on the international comity of States. Non-States actors do have a place in this international dynamic.

How then can we get ethnic and religious groups that are spread out in different States but that have bonds that are stronger than those they have with their States of nationality to join or support their States in their international cooperation agenda. It is now very clear that Southern Cameroons secessionists are getting support from their Biafra brothers who on their part expect support in return in their quest to form an independent State from Nigeria.

One can agree with Makau Mutua ${ }^{48}$ that the solution will be to redraw the map of Africa. Afterall, Erithrea after so many years succeeded in separating from Ethiopia and South Sudan also after several years of bloodshed succeeded in separating from Sudan. There are also examples of peaceful separation such as the separation of The Gambia from Senegal. 
Another approach can be to reinforce Federalism as a means of granting an amount of autonomy to certain groups within the national arrangement and in the most extreme cases, the possibility of creating a Confederation can be explored. Secession can only be contemplated in the worst-case scenario when it is found that the union has "irretrievably broken down". ${ }^{49}$ The former arguments are developed in greater detail in another paper. $^{50}$

\section{NOTAS}

1 There are several books, articles and documents on the Berlin Colonial Conference and the Partition of Africa one of the most recent of which is Thomas Pakenham's "The Scramble for Africa 1876 - 1912", Abacus, 1991 reprinted in 2010.

2 For a more detailed discussion on the creation of Nation States in Europe See Robert L. Carneiro, "A Theory of the Origin of the State", Science (1970) and Jeremy Black, "Maps and Politics", University of Chicago Press (2003)

3 See for this point essentially, Thomas Pakenham: The Scramble for Africa: Whiteman's Conquest of the Dark Continent from 1876 - 1912, Random House, (1991). And Darwin John: "Imperialism and the Victorians: The Dynamics of Territorial Expansion", English Historical Review (1997) 112 No 447 pp614 - 642.

4 See Michalopoulos, Stelios and Elias Papaioannou: "The Long Run Effects of the Scramble for Africa", CEPR Discussion Paper 8676 (2011)

5 The principle in international law that newly created States should have the same borders that their preceding dependent area had before their independence. In the case of African States, this principle ties them to the boundaries that were delineated by their former colonial masters before independence.

6 The Boko Haram insurgency began in 2009, when the jihadist rebel group Boko Haram started an armed rebellion against the government of Nigeria. In 2014, the insurgency spread to neighboring Cameroon, Chad, and Niger thus becoming a major regional conflict. In 2015, a coalition offensive forced Boko Haram to retreat into the Sambisa Forest. The insurgency took place within the context of long-standing issues of religious violence between Nigeria's Muslim and Christian communities.

7 For a brief non-academic history of the origins of the problem in Southern Cameroons and the Nigeria Biafra relationship, see https://en.wikipedia.org/wiki/Southern_Cameroons

8 Well determined kingdoms could be found in North, West, East, Central and Southern Africa. For a complete and comprehensive list of the kingdoms, see https://en.wikipedia.org/wiki/ List_of_kingdoms_in_pre-colonial_Africa

9 Maximilian Karl Emil Weber: "Economy and Society", Original Published (1922) posthumously by his Wife Marianne, University of California Press.

10 An example of a pre-colonial treaty is the Germano-Duala Treaty of 12 July 1884 whereby King Ndumbe Lobe Bell and King Akwa of Cameroons River signed a treaty in which they assigned sovereign rights, legislation and administration of their country in full to the German firms of Adolph Woermann and Janttzenand Thormahlen. For more details see: https://afrolegends. com/.../colonial-treaties-in-africa-the-germano-duala-treaty-of-12-j... (Accessed 20/05/2018)

11 See https://www.dw.com/en/130-years-ago-carving-up-africa-in-berlin/a-18278894.

12 Ibid

13 See infra Note 17.

14 The name was given by Fernando Po, the early Portuguese explorer who "discovered" Cameroon. 
15 See Treaty Between Great Britain and Lagos at https://en.wikipedia.org/.../Treaty_Between_Great_Britain_and_Lagos,_1_January_18... (Accessed 20/05/2018)

16 The treaty indicates the territory of the Cameroons situated in the Cameroons River between the Bimbia River on the North Side, the River Qua-Qua on the South side, and up to 4o 10' on the North side. More on the content and details of the Treaty is not for this paper but can be found online at www.afrolegends.com. However, for anyone who knows the geography of the area, it is easy to understand that such a description is indeterminate of the geographical zone called Cameroon or Cameroons.

17 The story is told of how a senior British official boasted about drawing a line with his blue pen to delimit the boundary between Nigeria and Cameroon (an area he had never been to) while sitting in his office in London. See JC Anene The international boundaries of Nigeria 1885-1960 (1970), cited in Ernest Duga Titanji "The Right of indigenous peoples to self-determination versus secession: one coin two faces?" published in the African Human Rights Law Journal, Volume 9 No 1, 2009 at p. 60: "In those days we just took a blue pencil and a ruler, and we put it at Old Calabar, and drew that line to Yola ... I recollect thinking when I was sitting having an audience with the Emir [of Yola], surrounded by his tribe, that it was a very good thing that he did not know that I, with a blue pencil, had drawn a line through his territory."

18 Case of the Land and Maritime Boundary between Cameroon and Nigeria (Cameroon v. Nigeria: Equatorial Guinea intervening), ICJ 2002.

19 Cameroon - Nigeria UN Commission

20 Law No. 2014/028 of 23 December 2014 on the suppression of acts of terrorism in Cameroon

21 See "The Terrorism Prevention Act", 2011.

22 See https://www.mnjtf.org (accessed 22 May 2018)

23 See generally W. Christian "Terrorism as a challenge for national and International law: Security versus Liberty?" Berlin Heidelberg (Springer 2003).

24 C. Lumina, "Counter-terrorism legislation and the protection of human rights: a survey of selected international practice" (2007) 1 AHRLJ 35-67.

25 The Annals of the American Academy of Political and Social Science, Volume 463 (1890). Page 12

26 See, note 43 infra.

27 B. Broomhall "State Actors in an International Definition of Terrorism from a Human Rights Perspective" CASE W. RES. J. INT'L L. Vol. 36:421, 2004 p 430-440.

28 See point "V" below.

29 A. Cohen "Prosecuting Terrorists at the International Criminal Court: Reevaluating an Unused Legal Tool to Combat Terrorism" Michigan State International Law Review Vol. 20:2, 2012 p 224-233.

30 International Federation for Human Rights, "Counter-Terrorism versus Human Rights: the Key to Compatibility", Analysis Report No 429/2 October 2005 available at https;/www.fidh.orh/IMG/ pdf/counterterrorism429a.pdf (accessed 2 may 2018)

31 Section 2(c)

32 Section 2 (b)

33 Section 8

34 Section 9

35 See www.africanews.com/.../cameroon-receives-ambazonia-leader-46-others-deported-fro... (accessed 23 May 2018)

36 J. Locke "Two Treatises of Government" Black swan, 1690.

37 Preamble of the UN Counter Terrorism Strategy Paper available at www.un.org/pga/70/wp-content/.../UN-Global-Counter-Terrorism-2-June-2016.pdf

38 Though there is no single definition of the concept of the 'rule of law', its essence was captured by former UN Secretary-General Kofi Annan in the context of transitional justice in conflict and post-conflict societies when he described the 'rule of law as "referring to a principle of governance in which all persons, institutions and entities, public and private, including the State itself, are accountable to laws that are publicly promulgated, equally enforced and independently adjudicated, and which are consistent with international human rights norms and standards." See "Security Council Stresses Importance, Urgency of Restoring Rule of Law in Post-Conflict Societies", 06 October 2004, para.6. Available at https://www.un.org/press/en/2004/sc8209.doc.htm 
39 See Amnesty International report of 12 January 2018: "Ten arrested Anglophone leaders at risk of unfair trial and torture if deported from Nigeria”. Available at https://www.amnesty.org/.../ cameroon-ten-arrested-anglophone-leaders-at-risk-of-unf...

Amnesty International Report of 13 October 2017: “Cameroon: Inmates 'packed like sardines' in overcrowded prisons following deadly Anglophone protests". Available at https://www.amnesty. org/.../cameroon-inmates-packed-like-sardines-in-overcrowded-...

40 Ayuk Tabe (the leader of the Cameroon Anglophone Movement) and Co (46 others) have been missing for 5 months. The Minister of Communications at least twice has acknowledged that they are in the keeping of the State of Cameroon but no one has seen them and they have not been allowed the visit oeir lawyers and family seen they were kidnapped from Nigeria.

41 See Section Article 14(1) ICCPR on Fair Trial: "...everyone shall be entitled to a fair and public hearing by a competent, independent and impartial tribunal established by law."

42 See Amnesty International Cameroon Human Rights Report 2017/2018 available at https:// www.amnesty.org/en/countries/africa/cameroon/report-cameroon/

43 (A/HRC/34/30 (2016) para. 56).

44 UNSC Res 1373 (28 September 2001) para 3;

45 See VII below

46 UN General Assembly (UNGA) Res 288/60 (8 September 2006) (UN CT Strategy).

47 See in general "Manual on the Course on Counter Terrorism for Universities" available at https:// www.unodc.org/e4j/en/tertiary/counter-terrorism.html. (accessed 2 September 2018)

48 Makau Wa Mutua, "Why Redraw the Map of Africa: A Moral and Legal Inquiry," 16 Michigan Journal of International Law 1113 (1995).

49 See Ernest Duga Titanji, supra.

50 Ibid

Recebido em: 5-10-2020

Autor convidado

Ernest Duga Titanji

Senior Lecturer of Laws - Faculty of Laws and Political Science University of Yaoundé II

Barrister and Solicitor of the Supreme Court of Cameroon. E-mail: dugatitanji@dugalaw.com|

Faculty of Laws and Political Science University of Yaoundé II

2016 Commonwealth Avenue, Apt \# 2B

Brighton, MA 02135 
